\title{
From Wealth to Power
}

Fareed Zakaria. Princeton: Princeton University Press, 1998. 199 pages.

From Wealth to Power is a study in the social and historical dynamics contributing to the rise and fall of essential actors in the international system. It attempts to join history with social science theory in order to shed light on broad theoretical topics in world politics, such as the rise of new great powers. In so doing it seeks to add to the body of scholarship which combines the study of state structure with traditional intemational relations theory. The particular focus is on the expansive rise of the United States, not only to world prominence, but also as a modem state. American foreign policy during the period 1865-1908 is examined in light of changes in the state structure along the four major variables: scope, autonomy, coherence and capacity, touching upon that country's domestic and administrative development. 
The first of the six chapters of the book poses the main questions which Zakaria attempts to address: "What turns rich nations into 'great powers?' " "Why, as states grow increasingly wealthy, do they build large armies, entangle themselves in politics beyond their borders, and seek international influence?" "What factors speed or retard the translation of material resources into political interests?", and finally, "Under what conditions do states expand their political interests abroad?" Such questions visualize, on the one hand, a strong and direct correlation between great powers' economic rise and fall and their growth or decline. Anomalies, on the other hand, are explained as a "Dutch disease," or the malady which does not allow "a nation of unequalled individual prosperity and commercial prowess to remain in a state of great influence and power." The latter, Zakaria claims, was an American affliction during the second half of the nineteenth century. This was particularly true during the relatively long period of non-expansion and isolation following the Civil War (1860-64). Despite a tremendous increase in wealth, productivity and power, it was not until the 1890 s that the US began expanding again. Zakaria considers this to be an aberration, reflecting a "highly unusual gap between power and interests," that lasted for some thirty years. An explanation, according to him, would not only require a full historical account, but more so, "first cut theories" which clarify national behavior.

The two theories he puts forth as potentially explanatory are those of classical (state-centered) realism and defensive realism. Beside discussing their merits and demerits, much of the rest of the study actually attempts to argue the superiority of the former theory. According to classical realism, power determines a nation's interests, and therefore the rate and limits of its expansion, not only in terms of imperialism, but more broadly its activist foreign policy and participation in great-power diplomacy. The more benign defensive theory, however, posits that states seek security rather than influence. They expand when threatened and not simply because they can. In the case of absence of a peril, states have no systemic incentive to aggrandize. Zakaria utilizes the US case study to demonstrate that the pattern of American foreign policy from the end of the Civil War to the close of Theodore Roosevelt's presidency (1901-1908) actually conformed to the assumptions and predictions of state-centered realism.

Chapter two basically expands on the conceptual theme, critically surveying the literature and the contending positions of different theoreticians. The most important analytical contribution in this chapter, 
however, is in making the clear distinction between state and national powers. According to the "state-centered realism" hypothesis, Zakaria argues that statesmen will expand their nation's political interests abroad when they perceive a relative increase in state power, not national power, depending, that is, on the fraction of the latter that the former can extract. This approach draws on a tradition that treats the state as an autonomous actor with great impact on national policy. Thus, at one end of the spectrum lie those states that are cohesive, autonomous, wealthy, and maximal, and at the opposite end lie those that are divided, societypenetrated, poor and minimal. The stronger the state, the greater its ability to extract national power for its ends. The strength of this hypothesis lies in its continued upholding of "power" as a critical variable, thus maintaining the over-all logic of classical realism. It further adds greater sophistication and precision in measuring power, allowing for the development of a more accurate theory, without any real loss of parsimony.

Chapter three is more of a historical survey, which attempts to trace the reasons behind the glaring disparity between "America's strength and its paltry influence abroad." Despite the tremendous resources at its disposal and its almost meteoric economic and industrial growth from the end of the Civil War until the 1890s, it became evident to major European actors that the United States was not actually translating its rising power into political activism abroad. Zakaria provides counter-factual arguments against those who had offered different explanations for such an historical aberration. He purports, through the study, to examine fifty-four cases of distinct opportunities to expand between 1865 and 1908, broken down in a period of non-expansion (1865-1889) and that of expansion (1889-1908). He proceeds to state that, although in testing the theories of state-centered realism and defensive realism both accorded with some cases, the former theory actually explained American behavior much more. As a matter of fact, and counter to defensive realism's predictions, when the United States faced threats from abroad, it did not expand, it retrenched. Reasons for non-expansion thus were not to be found in American isolationism, the social and economic after-effects of the Civil War, or in a profound sense of security, but rather in the fact that the American state was "weak, divided and decentralized," providing policymakers with "little usable power." The very structure of the political system and the constant strife between the executive and the Senate, which sought to wrest control of foreign policy, prevented expansionist visions such as those of Secretary 
of State William Henry Seward from coming to fruition. Once this situation had been rectified with the birth of the modern presidency under William McKinley (1897-1901), there emerged a symbiotic relationship between national executive power and foreign policy activism that continued throughout the twentieth century.

In chapter four, Zakaria traces the changing structure of American politics in light of the relative shifts of state power. The significance of such elaboration rests on the idea that state structures affect policy outcomes, an intellectual contribution which "lies at the heart of the renaissance in scholarship that has over the last two decades revived the concept of the autonomous state." Between the late 1870 s and the late 1890 s, the two key institutions of the federal government and the presidency gained in ascendancy vis-a-vis the congress. They became the primary institutions and mechanisms through which national power could be converted into international influence. However, unlike European states such as France or Germany, the rise of the American state during the period under study was qualitatively weaker. Reasons had largely to do with the fact that its autonomy grew in response to pressures generated by industrialization, rather than as a reaction to visible external threats. And while state building did occur in the decades following the Civil War, nevertheless, it was "state building as patchwork." Only later were there systematic attempts at consolidating a pattern of construction. This involved strengthening the presidency and the appropriation of emergency powers, reforming the civil service and weakening the spoils and patronage systems, and expanding the foreign service and the armed forces. By 1890 , control of the American state and its extraordinary resources had firmly been thrust into the hands of central decision-makers who were alert to the opportunities the international system presented and to the immense resources at their disposal. A more coherent foreign policy thus could be pursued by the presidency. This nascent strength of the new American state made possible the emergence of the United States onto the world stage in the late 1890 s.

Chapter 5 expands on the above theme, and surveys the historical and aggressive expansion of American interests in tandem with that country's rise in state and national power during the period 1889-1908. The new diplomacy of the United States, generally associated with the administration of Benjamin Harrison (1889-1893), coveted the annexation of Hawaii, Cuba, Puerto Rico, and possibly even Canada. From thereon, American 
expansionism, particularly to the South in Central and Latin America, but also in Asia, never ceased, and spilled over into the twentieth century. During the decades after World War II, the United States, according to Zakaria, possessed virtually unchallenged control over its international environment. It constructed in the process a systemic order favorable to American interests, which reflected its final transformation to great power status.

Finally, the study concludes that of twenty-two opportunities to expand between 1865 and 1889 , state-centered realism has proven to be the better explanation in fifteen cases and defensive realism in just two. The remaining five cases were too vague to allow for any definite conclusions. As for the more expansionist period (1889-1908), of thirty-two distinct opportunities, twenty-five were seized, again confirming predictions of state-centered realism. Thus, Zakaria arrives at the conclusion that the test of the validity of two first-cut theories of foreign policies confirm the power-based interpretation of American expansionism - the expansionism of a strong nation, but a weak state.

Zakaria makes an extremely important analytical contribution in highlighting the distinction between state and national powers. But at the same time, his study gives rise to a measure of ambivalence. On the one hand, he explains well a phase in American history, and provides an analytical tool for examining more recent events concerning not only the United States, but also other nations. For instance, it could be instrumental in explaining why the former lost the war in Vietnam. The Vietnamese state was more capable of organizing, mobilizing and therefore, extracting resources from society in a way that the United States, despite its overwhelming assets, could not do. It could also shed new light on why the Arabs have failed in confronting and defeating Israel, despite the tremendous resources at their disposal, and notwithstanding American support for that state. In essence, the analytical distinction does show that social and political organization are the main determinants of outcomes, rather than mere resources. A profound observation no doubt, and in many ways logical and commonsensical. Yet on the other hand, Zakaria's argument, which essentially asserts that the United States did not expand for thirty years because it first had to consolidate domestically, borders on the tautological; an inherently paradoxical situation when stating the obvious which, for a myriad of reasons, had been obscured by images and perceptions of awe. It further leaves open the question about the role that 
national power and resources play in expansion despite less than optimal organization. For example, Zakaria does not touch in any significant measure upon the Monroe Doctrine (1823), which basically established US hegemony over Latin America. Could it be because it may have provided ample ammunition for proponents of defensive realism? In downplaying some factors while highlighting others, Zakaria confronts the same biased and reductionist dilemmas which face most studies seeking, in the name of parsimony and theory building, to reduce the explanation of multifaceted, multidimensional phenomena to some basic or core reason. As a matter of fact, he admits that studies which stressed different factors would "no doubt be more accurate." And yet, he insists that a full historical account cannot explain the general dynamic motivating American foreign policy that resulted in non-expansion in the 1870 s and 1880 s, and yet expansion in the 1890 s. He cites an example wherein historians attributed both to adverse economic conditions. If similar economic conditions explain an occurrence and its opposite, "how central" Zakaria asks, "can this factor be?" A resultant policy, however, may not be solely the outcome of one or the sum of several factors, but of something greater than the sum. Furthermore, the same input in different temporal and spatial conditions may produce different or even opposite outcomes, with one input (economics in this case) still playing a causal role among others (e.g., dialectics?). This introduces the elements of both indeterminacy and the composite effects of conglomerate opposing pressures. Yet it was the will for parsimony which seems to have induced Zakaria to play down the combined effects of the Civil War and economic conditions, in addition to the organizational aspects, on the American policy of non-expansion. At one time he dismissively states that the Civil war "left only slight impressions on the American state." Yet this seems to underplay its crucial role in molding an American national identity, a necessary condition for any subsequent expansionist thrust, and which of course needed time to strike roots. The defeat of the South, further, did not simply involve the vanquishing of an army, but the transformation of a whole way of life among a significant part of the nation. Thirty years in this respect is not necessarily a long time. One would imagine that it would take at least a generation for a nation as young as the United States to harvest the fruits. In fact, one can argue that thirty years were a relatively short time for such a feat to be accomplished. Even if the state had retrenched after the defeat of the South, as Zakaria claims, the war nevertheless, had proven that 
resources could be extracted - if and when needed - for conducting what, until this day, is tantamount to the bloodiest war in American history.

At other times, Zakaria seems to contradict himself when he admits that the material costs of the Civil War had been immense, with the United States burdened with a national debt of unprecedented proportions. Even if the American economy and population were growing so rapidly as to make the debt relatively painless, as he put it, should one not take into consideration the role of perceptions and psychological fatigue, instead of just invoking statist explanations? And if so, does this not undermine the solidity of the latter as the independent variable? If perceptions of impoverishment had not existed, for instance, and despite the Congress bickering with the Executive, would policy outcome have been different? This important question should have been clearly addressed in order to gage the strength of structural weakness as an explanation. As a matter of fact, Zakaria admits at one point that it was post-war economic depression which dampened the expansionist mood to extend American influence into Cuba. In another place, he recognizes that when financial constraints appeared to loosen by the early 1880 s, the Congress became more receptive to governmental demands for increased spending in certain areas. The structural variable appears to lose its explanatory power in the process. More detrimental to his argument is where he seems to indicate that the augmented strength of the state was more a function of the increase in national power than the opposite. "The growth of national economy," as Zakaria put it, "was creating the need for a national professional bureaucracy," which together with a petered-out congressional bid for supremacy, served to strengthen the executive office. By implication, the petered- out powers of the congress were also significantly influenced by economic and resource factors. It is growth in national power which allows the state to consolidate and become a stronger state. In essence, we are having a situation where national power explains state power. The independent variable becomes blurred with the dependent variable to be accounted for! Analytical distinctions require more precision than this commendable work could actually provide. At the heart of this paradox lies the ambivalence of Zakaria's study.

From Wealth to Power nevertheless, remains a recommended book for those who need to be introduced to American history and foreign policy. It offers insights which the current power of the United States may have served to obscure. Its analytical contribution could further serve to refocus 
priorities, questions and concerns in areas as diverse as the Arab/Islamic world and the European Union. Why both, for instance, despite many factors in their favor, could not pursue a unified and coherent foreign and defense policy, and thus increase their relative intemational stature? This may provide for a potentially interesting comparative study, beyond which one may further proceed to examine the question of the necessity of an Islamic State. Not solely in the sense of applying the shari'ah, but more so as a supra non-territorial state that can extract the resources of the 'Umma, based on structure and process as well as Islamic values. The relationship between state extractive structures and national power may be the place to start from.

Amr Sabet Halmstad University Sweden 